\title{
The Review of SARS-CoV-2: Recent Perspective and Advances in Detection
}

\section{A R T I C L E I N F O}

\section{Article Type}

Review Article

\section{Authors}

Hajar Mohammadi Barzelighi, $P h D^{1}$ Bahram Daraei, $P h D^{2^{*}}$
How to cite this article Mohammadi Barzelighi H., Darae B. The Review of SARS-CoV-2: Recent Perspective and Advances in Detection. Infection Epidemiology and Microbiology. 2020;6(3) 229-249

${ }^{1}$ Biosun Pharmed Factory, Barkat Pharmaceutical group, Tehran, Iran ${ }^{2}$ Department of Toxicology and Pharmacology, School of Pharmacy, Shahid Beheshti University of Medical Sciences, Tehran, Iran

\section{* Correspondence}

Address: Department of Toxicology and Pharmacology, School of Pharmacy, Shahid Beheshti University of Medical Sciences, Valiasr Ave., Tehran, Iran.

Bdaraei@sbmu.ac.ir

\section{Article History}

Received: July 15,2020

Accepted: August 05,2020

Published:August 15,2020

\section{A B S T R A C T}

Background: The outbreak of novel coronavirus (2019-nCoV), which began in Wuhan, China, has rapidly spread in many countries and is currently considered a pandemic. The virus (SARS-CoV-2) causes severe acute respiratory syndrome and is related to SARS-CoV and MERS-CoV.

Methods: In this review, an introduction to SARS-CoV-2 was provided comprising the following items: general features; pathogenesis; the existing knowledge on immunological properties; transmission routs; diagnostic features, especially discussion about new approaches for treatment and prevention; and different diagnostic methods including nucleic acid based assays, serological testing, and MALDI TOF-MS and LC-MS technologies. Findings and Conclusion: Introducing the different methods for SARS-CoV-2 detection may be useful to provide new insights into the development and improvement of detection primers, probes, methods/techniques, potential targets for drug designation, and therapeutic candidates against the virus.

Keywords: 2019-nCoV; Acute respiratory syndrome; Nucleic acid base assays; Serological testing; MALDI TOF-MS and LC-MS.

\section{CITATION LINKS}

[1] Zhang N, Wang L, ... [2] Huang P, Wang H, ... [3] Gorbalenya AE, Enjuanes L,... [4] Channappanavar ... [5] Xie C, Jiang L, Huang G, ... [6] Wu F, Zhao S, Yu B, ... [7] World Health Organization. [8] World Health Organization. [9] Zhou P, Yang X-L, Wang ... [10] Cascella M, Rajnik M, Cuomo A, ... [11] Chan JF-W, Kok K-H, Zhu Z, Chu H, To KK-W, Yuan S, et al. ... [12] Perlman S, Netland J... [13] Lu X, Whitaker B, Sakthivel ... [14] Li F. Structure, function, ... [15] Rothan HA, ... [16] Lei J, Li J, Li X, Qi X. CT imaging of ... [17] Huang C, Wang Y, Li X, Ren L, ... [18] Wrapp D, Wang N, ... [19] Wan Y, Shang J, Graham R, ... [20] Imai Y, Kuba K, Rao S, ... [21] Zhao Y, Zhao Z, Wang Y, Zhou Y, Ma Y, Zuo W. .... [22] Zhang H, Kang Z, Gong H, Xu D, Wang J, Li Z, et al. ... [23] Chai X, Hu L, Zhang Y, Han W, Lu Z, Ke A, et al. ... [24] Zou X, Chen K, Zou J, Han P, Hao J, Han Z, et al. ... [25] Xu H, Zhong L, Deng J, Peng J, Dan H, Zeng X, et al. ... [26] Zhang H, Penninger JM, Li Y, Zhong N, ... [27] Hoffmann M, Kleine-Weber H, Krüger N, ... [28] Shehata MM, Gomaa MR, Ali MA, Kayali G. ... [29] Iwata-Yoshikawa N, Okamura T, Shimizu Y, Hasegawa H, Takeda M, Nagata N. ... [30] Belouzard S, Chu VC, Whittaker GR. ... [31] Mille JK, ... [32] Wang H, Yang P, Liu K, Guo F, Zhang Y, Zhang G, et al. ... [33] De Wit E, Van Doremalen N, Falzarano D, Munster VJ.... [34] Li X, Geng M, Peng Y, Meng L, Lu S. ... [35] Zhu J, Yamane H, ... [36] Diao B, Wang C, Tan Y, Chen X, Liu Y, Ning L, et al. ... [37] Qin C, Zhou L, Hu Z, Zhang S, Yang S, Tao Y, et al. ... [38] Min CK, Cheon S, Ha NY, Sohn KM, Kim Y, Aigerim A, et al. ... [39] Li G, Chen X, Xu A. ... [40] Snijder EJ, Van der Meer Y, ... [41] Belser JA, Rota PA, Tumpey TM. Ocular ... [42] Lu CW, Liu XF, Jia ZF. 2019-nCoV ... [43] Peng X, Xu X, ... [44] To KK, Tsang OT, Yip CC, Chan KH, Wu TC, Chan JM. ... [45] Cooley H, Gleick PH, Abraham S, Cai W. ... [46] Xiao F, Tang M, ... [47] Wang W, Xu Y, Gao R, ... [48] Seah I, Su X, ... [49] Xiang J,Yan M... [50] Shanmugaraj B, Siriwattananon K, ... [51] Guan W-J, ... [52] Pan Y, Guan H, Zhou S, ... [53] Shi H, Han X, Jiang N, Cao Y, Alwalid O, ... [54] Jiang G, Renc X, Liu Y, ... [55] World Health ... [56] Centers for Disease ... [57] Zhang J, Wang S, ... [58] Shen M, Zhou Y, Ye J, ... [59] Setianingsih TY, Wiyatno A, ... [60] Adachi D, Johnson G, ... [61] Corman VM, Landt O, ... [62] Van Elden LJR, Van Loon AM, ... [63] Yip SP, To SST, Leung PH, ... [64] Hadjinicolaou AV, Farcas GA, Demetriou VL, ... [65] HKU Med. Detection of 2019 ... [66] Nao N, Shirato K, Katano H, ... [67] Centers for Disease ... [68] Jung YJ, Park G-S, Moon JH, ... [69] World Health ... [70] Chu DKW, Pan Y, ... [71] Corman VM, Landt O, ... [72] WOrld Health ... [73] Chan JF-W, Yip CC-Y, ... [74] Corman VM, Eckerle I, Bleicker T, Zaki A, ... [75] Lan L, Xu D, Ye G, Xia C, ... [76] Xie X, Zhong Z, Zhao W, Zheng C, ... [77] Poon LLM, Leung CSW, ... [78] Pyrc K, Milewska A, ... [79] Thai HTC, Le MQ Vuong CD, ... [80] Shirato K, Semba S, El-Kafrawy SA, ... [81] Shi R, Ma W, Wu Q Zhang B, ... [82] Guo X, Geng P, Wang ... [83] Gootenberg JS, Abudayyeh 00, ... [84] Broughton JP, Deng X, Yu G, ... [85] Zhang F, Abudayyeh OO, ... [86] Hou T, Zeng W, Yang M, ... [87] Li Z, Yi Y, Luo X, Xiong N, Liu Y, Li S, et al. ... [88] Chen X, Zhou B, Li M, Liang X, Wang H, Yang G, et al. ... [89] Serology testing and COVID ... [90] Tian X, Li C, Huang A, Xia S, ... [91] Liu N, Wang L, Cai G, Zhang D, Lin J... [92] Trauger SA, Junker T, ... [93] Xiu L, Zhang C, Wu Z, Peng J... [94] Sampath R, Hofstadler SA, ... [95] Jenkins C, Orsburn B. .. [96] Jenkins C, Orsburn B. In silico approach to accelerate the development of mass... 


\section{Introduction}

Themajorcausativeagentsofviralrespiratory diseases (RD) include coronavirus, influenza virus, rhinovirus, respiratory syncytial virus (RSV), and adenovirus ${ }^{[1]}$.

Coronaviruses belong to the Nidovirales order, Coronaviridae family, and Coronavirinae subfamily. They contain single, large, plusstranded RNA as their genome and may cause respiratory, hepatic, enteric, and neurological diseases ${ }^{[2-3]}$. These viruses could infect a wide range of animals including carnivores, rodents, birds, humans, and other mammals ${ }^{[2]}$.

Until now, six human coronaviruses (HCoVs) have been identified, including HCoV-HKU1, HCoV-229E, HCoV-NL63, HCoV-OC43, severe acute respiratory syndrome coronavirus (SARS-CoV), and Middle East respiratory syndrome coronavirus (MERSCoV) ${ }^{[4]}$. Some members of the coronaviruses, specifically SARS-CoV and MERS-CoV, are extremely pathogenic, evolving, and reemerging coronaviruses which may cause epidemics or pandemics ${ }^{[1]}$. In December 2019, the office of the World Health Organization (WHO) in China reported some cases of pneumonia in Wuhan, Hubei province in China; one week later, the causative agent was identified as a novel coronavirus (2019nCoV) or SARS-CoV-2, and Chinese National Health Commission provided guidance to laboratory diagnoses ${ }^{[5-6]}$. The bioinformatics analysis revealed that the new virus has the typical structures of coronaviruses ${ }^{[5]}$. The disease outbreak began from a local seafood market, disseminated significantly, and infected Chines people, leading to 3,242 deaths in China and subsequently leading to the infection of 209, 839 people worldwide with 8,778 deaths as of March 19, 2020 [7]. WHO declared the disease as pandemic on March 12, $2020^{[8] .}$

Objectives: In this study, at first, an overview was provided about the virus structure, pathogenesis, treatment, and diagnosis, and then different detection methods were focused on.

\section{Virus structure}

Viral particles in infected cells display a typical coronavirus morphology with approximately $60-140 \mathrm{~nm}$ in diameter by electron microscopy ${ }^{[9-10]}$ and a genomic structure of +ssRNA with approximately $29891 \mathrm{bp}(30 \mathrm{~kb})$ in length ${ }^{[11]}$ (the largest known RNA viruses), containing a $5^{\prime}$-cap structure and $3^{\prime}$-poly-A tail ${ }^{[10,12]}$. It comprises of two flanking untranslated regions (UTRs) and a single long open reading frame (ORF) encoding a polyprotein including 9860 amino acids with $38 \% \mathrm{G}+\mathrm{C}$ content ${ }^{[11]}$. The sequence of viral genome was released immediately by public health support via the community online resource virological. org on January 10, 2020 (Wuhan-Hu-1, GenBank Accession Number MN908947); subsequently, other four genomes were deposited in the viral sequence databases on January $12^{[13]}$.

The proteome of virus contains envelope protein (E), spike protein (S), membrane protein $(\mathrm{M})$, nucleoprotein $(\mathrm{N})$, and nonstructural proteins such as RNA polymerase, papain-like protease, 3-chymotrypsinlike protease, glycoprotein, helicase, and accessory proteins ${ }^{[6,9,14]}$, arranged in the order of $5^{\prime}$ to $3^{\prime}{ }^{[11]}$.

Spike glycoprotein comprises of two subunits: S1 and S2 ${ }^{[11]}$. The S1 subunit contains three segments: a receptor-binding domain (RBD), an N-terminal domain (NTD), and a signal peptide (SP); the S2 subunit encompasses cytoplasmic domain (CP), transmembrane domain (TM), heptad repeat (HR) 1 and 2 and fusion peptide (FP) (22). It has been reported that the S2 subunit is very conserved and shows 99\% identity with that of bat SARSlike CoVs (SL-CoVZXC21 and ZC45) and human SARS-CoV ${ }^{[11]}$ and could be targeted by a broad spectrum of antiviral therapies [11]. RBD contains a highly-conserved core 
domain and an external subdomain on which most of the amino acid differences are located and is involved in direct interaction with the host receptor [11]. Angiotensin-converting enzyme 2 (ACE2) is probably a functional cell receptor for 2019-nCoV, mediating virus enterance into host cells ${ }^{9} \mathrm{a}$ large number of severe acute respiratory syndrome-related coronaviruses (SARSr-CoV).

Zhou et al. (2020) analyzed 5 samples of 2019-nCoV metagenomically using next generation sequencing (GenBank Accession Number AY278488.2, and GISAID Accession Numbers EPI_ISL_402127-402130), which were identical more than $99.9 \%{ }^{[9]}$. They reported that the virus genome contained six main ORFs which were common to other coronaviruses and several other accessory genes. The direction of genes $\left(5^{\prime}\right.$ to $\left.3^{\prime}\right)$ was reported to be as follows: replicase ORF1ab, spike (S), envelope (E), membrane (M), and nucleocapsid (N) (Figure 1) ${ }^{[6]}$. The ORF1ab, $\mathrm{S}, \mathrm{ORF} 3 \mathrm{a}, \mathrm{E}, \mathrm{M}$, and $\mathrm{N}$ genes were determined to be proteins with 21,291 nucleotides (nt) ${ }^{[6]}$. Furthermore, the strain WHCV viral genome was determined to be similar to SARS-CoV, while harboring a predicted ORF8 gene with $366 \mathrm{nt}$ in length, located between the $\mathrm{N}$ and M genes ${ }^{[6]}$. In another study, $94.4 \%$ similarity was found in amino acid sequences of seven conserved replicase domains of ORF1ab between 2019-nCoV and SARS-CoV, which were used for $\mathrm{CoV}$ species classification. However, nucleotide sequence similarity of other genes between 2019-nCoV and SARSCoV was determined as $80 \%{ }^{[9]}$. Also, $96.2 \%$ identity was found between $2019-\mathrm{nCoV}$ and bat-derived coronavirus (BatCoV RaTG13) sequences; BatCoV RaTG13 seems to be closely related to $2019-\mathrm{nCoV}$. The S gene encoding receptor-binding spike protein of 2019-nCoV was shown to have less than 75\% and nearby 93.1\% nucleotide sequence identity to that of SARSr-CoVs and RaTG13, respectively ${ }^{[9]}$. The $\mathrm{S}$ gene sequence of 2019 -
nCoV in comparison to SARS-CoV contained three short insertions in the $\mathrm{N}$-terminal domain, conferring sialic acid binding activity as well as changes in four out of five significant residues in the receptor-binding motif ${ }^{[9]}$. The phylogenetic analysis provided evidence for the origination of 2019-nCoV from RaTG13 [9].

In another study by $\mathrm{Wu}$ et al. (2020), the bronchoalveolar lavage fluid (BALF) was collected from symptomatic patients and analyzed by meta-transcriptomic sequencing, showing a close relatedness to the bat SARS-like coronavirus (CoV) with $89.1 \%$ nucleotide identity (GenBank Accession Number MN908947). Their phylogenetic relatedness analysis with respect to the $S$ gene determined that clinical strains of WHCV were most closely correlated to the bat coronavirus SL-CoVZC45 with $82.3 \%$ identity in amino acid sequences ${ }^{[6]}$. According to ORF1b analysis, they proposed that the strains belonged to Sarbecovirus cluster, it may be due to the recombination among the bat sarbecoviruses ${ }^{[6]}$. It was also shown that spike protein of RBD was closely related to those of SARS-like CoVs and SARSCoVs with about 75.9-76.9\% and 73.8-74.9 amino acid identity, respectively, indicating the virus ability to enter cell using human ACE2 receptor ${ }^{[9]}$.

\section{Pathogenesis}

The increase in mortality rate due to SARSCoV-2 infection is concomitant with severe symptoms of the illness ${ }^{[15]}$. Infected people exhibit higher leukocytes number, lower lymphocytes number, rough breath sounds, increased amounts of pro-inflammatory cytokines in plasma, increased levels of C-reactive proteins in the blood, elevated erythrocyte sedimentation rate, and increased D dimer rate ${ }^{[16]}$. The complications such as acute respiratory distress syndrome (patchy consolidation in multiple regions and ground-glass opacities in both lungs), 
RNAaemia, acute cardiac injury, secondary infection, and high plasma levels of IL2, IL10, IL7, GSCF, IP10, MIP1A, MCP1, and TNF $\alpha$ are the main pathogenesis of COVID19 disease, especially in ICU-admitted patients ${ }^{[16-17]}$. The mechanism of virus entry and immunological responses would be described.

Virus entry to cell: It has been determined that SARS-CoV-2 S protein (forming trimers with two of RBDs facing one direction and the other one facing the opposite way) ${ }^{[18]}$ has a great affinity to bind to human ACE2 according to crystal structure analysis and biochemical interaction ${ }^{[18]}$, and that glutamine (residue 394) in the RBD of SARSCoV-2 could be recognized by the critical residue on human ACE2 receptor lysine 31). SARS-CoV-2 RBD identifies and binds to ACE2 more efficiently than SARS-CoV RBD, increasing SARS-CoV-2 ability to transmit from human to human ${ }^{[19]}$. Overall, ACE2 is required for SARS-CoV-2 entrance to host cell and following viral replication [20]. The overexpression of human receptors has been shown to enhance the severity of disease in mouse model, demonstrating that the step 1 (virus attachment and penetration) is a critical step in the virus pathogenesis. ACE2 has been shown to play a significant role not only in virus entrance but also in the lung injury so that blocking of the renin-angiotensin pathway could attenuate/ decrease the lung injury ${ }^{[20]}$. High expression level of ACE2 has been detected in alveolar type II cells (AT2) of the lung [21], upper esophagus stratified epithelial cells [22], clonal and ileal absorptive enterocytes [22], bile duct choanocytes ${ }^{[23]}$, myocardial cells ${ }^{[24]}$, kidney proximal tubular cells ${ }^{[24]}$, bladder urothelial cells ${ }^{[24]}$, and mucus of oral cavity, especially in tongue epithelial cells ${ }^{[25]}$. These findings explain the susceptibility of the above organs to the virus entry [24-25].

Activation of Sprotein via cellular transmembrane protease serine 2
(TMPRSS2) has been shown to be essential for viral penetration and spread [26-29]. Proteolytic cleavage of SARS-CoV-2 S protein (at 797 position) has also been shown to mediate the fusion of virus into the membrane and virus entrance in the early step ${ }^{[30]}$. In the case of MERS-CoV, S protein has been shown to be activated by Furin, a broadly expressed protease in human cells, by a two-step cleavage occurring in distinct sites ${ }^{[31]}$. It has also been determined that SARS-CoV entry is mediated by a clathrin and caveolae-independent mechanism [32]. SARS-CoV and MERS-CoV RNA have distinct translation mechanisms ${ }^{[33]}$.

Approximately two-thirds of the viral genome is translated to two large polyproteins, and the remains is transcribed into subgenomic mRNAs ${ }^{[33]}$ (Figure 1). The replicase polyproteins pp1a and pp1ab are cleaved into 16 putative non-structural proteins (nsps), including two viral cysteine proteases; papain-like (nsp3), chymotrypsin-like, 3C-like, or main proteases (nsp5); RNAdependent RNA polymerase (RdRp)/nsp12; helicase (nsp13); and other nsps which are probably involved in the replication and transcription of the virus [11]. The orfs and nsps of 2019-nCoV and SARS-CoV are similar, and the major discrepancy is in orf3b, spike, and orf8 [11]. Orf3b encodes a fully novel short protein, new orf8 may encode a secreted protein containing an alpha-helix with a beta-sheet (s) ${ }^{[11]}$.

The newly expressed $\mathrm{E}$ is combined with RNA and $\mathrm{N}$ proteins to form nucleocapsid and buddd ER-Golgi intermediate compartment; finally, virions are released from the cell by fusing the vesicles with cytoplasmic membrane ${ }^{[33]}$.

Immunological processes: When the virus enters the cell and replicates, the antigen presentation is performed by the major histocompatibility complex (MHC) [34]. Unfortunately, there is still no report about 
antigen presentation of SARS-CoV-2, and our knowledge is according to previous research on MERS-CoV and SARS-CoV. The presentation of SARS-CoV antigens is principally based on MHC I molecules activity, although MHC II molecules also play a role ${ }^{[34]}$. It has been determined that the polymorphism of human leukocyte antigen (HLA) and human mannose-binding lectin (hMBL) is correlated with the susceptibility to SARS-CoV and MERS-CoV infections ${ }^{[34]}$. If this is also true about COVID 19 infection, it may explain the disease severity some human populations and specific races.

$\mathrm{T}$ cells play an essential role in virus eradication. CD8 cytotoxic T cells (CTLs) have the ability to secret a series of molecules, such as granzymes, perforin, and IFN- $\gamma$, to clear viruses from the host. Besides, $\mathrm{CD}^{+}$helper $\mathrm{T}$ cells (Th) could enhance and maintain cytotoxic $\mathrm{T}$ cells responses and support $\mathrm{B}$ cells in antibody production ${ }^{[35-36]}$. The total number of $\mathrm{T}$ cells (CTLs and Th) has been determined to be intensely decreased in SARS-CoV-2 infection, especially in suspected and intensive care unit (ICU) patients ${ }^{[36]}$. T cell reduction is negatively linked to patient's survival. It has also been demonstrated that $\mathrm{T}$ cell count has a reverse effect on IL-10, IL6 , and TNF- $\alpha$ concentrations in the blood; on the other hand, cytokines IL-6, IL-10, and TNF- $\alpha$ might mediate $T$ cell reduction [36]. Furthermore, CTLs and Th in infected patients with SARS-CoV-2 significantly possess higher amounts of Programmed cell death protein-1 (PD-1) and T-cell immunoglobulin mucin-3 (tim-3) as a marker of exhausted T cells, especially in the symptomatic stage. It has been indicated that in severe cases, the naïve Th cells percentage increases, while memory Th and regulatory T cells count decreases ${ }^{[37]}$. In severe cases, the count of natural killer cells and B lymphocytes decreases, while the serum level of TNF- $\alpha$, IL-6, IL- 1 , and IL-8 increases compared to cases with mild infection ${ }^{[37]}$. The elevated pro-inflammatory cytokines may be correlated to the severity and progression of the disease and SARS$\mathrm{CoV}-2$ pathogenesis. The main leading cause of death in patients with COVID 19 is acute respiratory distress syndrome (ARDS) ${ }^{[17]}$. The cytokine storm is one of the main mechanisms of ARDS. The release of large amount of proinflammatory cytokines (IFN- $\gamma$, IFN- $\alpha$, IL-6, IL-1 $\beta$, IL-18, IL-12, IL-33, TGF $\beta$, and TNF- $\alpha$ ) and chemokines (CCL2, CCL3, CCL5, CXCL8, CXCL9, and CXCL10) has been reported in SARC-CoV patients ${ }^{[4]}$. In the case of MERS$\mathrm{CoV}$, high levels of IL- 6 and IFN- $\alpha$ as well as CCL5, CXCL8, and CXCL-10 have been found in the serum of severely ill patients compared to moderately ill patients ${ }^{[38]}$.

The production of IgM and IgG ( $\mathrm{S}$ and $\mathrm{N}$ specific antibodies) against SARS-CoV virus has been well established ${ }^{[18]}$. It has also been demonstrated that IgM antibodies are presented until the end of Week 12, but IgG antibodies remains for a long time ${ }^{[39]}$. COVID 19 is assumed to follow a similar pattern.

SARS-CoV and MERS-CoV have developed various strategies to evade immune responses. The viruses avoid the dsRNA detection by the host immune system through inducing double-membrane vesicles production with no pattern recognition receptors (PRRs) and hiding the viral replication complex ${ }^{[40]}$. Another mechanism established for immune-evasion in MERS$\mathrm{CoV}$ is the downregulation of genes involved in antigen presentation via DNA methylation [4]. The immune-evasion mechanism of coronavirus could be considered as a new approach to COVID 19 therapy.

Transmission route: The common transmission routes of COVID19 include human to human contact (through coughing, sneezing, droplet inhalation, eye mucous, oral, nasal, and membranes) and direct contact with symptomatic and asymptomatic patients ${ }^{[10]}$. It seems that eye exposure may be 
an effective route for the virus transmission [41]. The ocular tropism of coronavirus (NL63, SARS) has been determined, and body fluids and infectious droplets could simply contaminate the conjunctival epithelium of human with 2019-nCoV [42]. Direct or indirect contact, inhalation of large or small droplets ${ }^{[43]}$, saliva ${ }^{[44]}$, and aerosols are also important routes for virus spread. 2019-nCoV has been detected in the some patients' feces ${ }^{[45]}$, there is also evidence of SARS-CoV-2 gastrointestinal infection, shedding of live virus in feces, and possible fecal-oral transmission route [46-47]. According to CDC report, the transmission of the virus through sewerage systems is low [41], although transmission through this route may be possible, but there is no evidence to date [41]. Medical healthcare workers, including physicians, nurses, laboratory experts, ophthalmologists, and dentists may be particularly at higher risk of COVID-19 infection ${ }^{[43,48]}$.

Diagnosis is based on the findings of clinical history, chest radiography, and laboratory assays ${ }^{[49]}$.

\section{Clinical symptoms}

The incubation time could be mostly 3-7 days and up to 2 weeks, and the longest time for the onset of infection symptoms is 12.5 days but usually appear 2 to 14 days after virus exposure [45, 50]. Clinical manifestations of the illness include dry cough, fever, dyspnoea, pain, weakness, and pneumonia. The disease may be the consequence of progressive respiratory failure due to alveolar injury which could be observed by CT scan (transverse chest computerized-tomography images), less common symptoms are headache, sputum production, sore throat, hemoptysis, and diarrhea ${ }^{[51]}$. The criteria for diagnosing the disease by clinician include virus-induced pneumonia; arisein body temperature; dizzy; Lymphocytopenia; higher leukocytes counts (although levels are normal sometimes) and neutrophil-lymphocyte ratio (NLR); lower percentages of eosinophils, basophils, and monocytes [37]; hypoxemia (after onset of the disease); pulmonary infiltrates on chest radiography; and kidney failure ${ }^{[6,9,24]}$.

Chest CT: CT scan is an important technique in the diagnosis of the lung disease. Highresolution CT (HRCT) of the chest is critical for early diagnosis and assessment of disease severity in patients with SARS-CoV-2 [52]. Differentradiologicalalterationsinthelungs of SARS-CoV-2 patients have been characterized at different times of the disease course. The abnormalities of CT imaging, in symptomatic and asymptomatic patients, happen rapidly and progress from focal unilateral to diffuse bilateral, subpleural, ground-glass opacities which evolve to or co-exist with consolidations peaking within 1-3 weeks or around 2 weeks after the disease onset [53]. The chest CT specificity is comparatively low and could not differentiate SARS-CoV-2 infection from other chest infection, alone ${ }^{[54]}$. It seems the combination of imaging features, laboratory and clinical results could facilitate early diagnosis of SARS-CoV-2 pneumonia ${ }^{[54]}$. Laboratory detection of COVID 19 would be described in detail in a separate section.

\section{Detection}

Laboratory detection: Exact and fast diagnosis of the etiological agent is important for determining the suitable treatment, saving people lives, epidemiologic monitoring, taking effective preventive steps, breaking epidemics, and decreasing unnecessary use of drugs. Poor clinical description and absence of special prevention methodsand treatmentapproaches mean that early diagnosis is critical. The viral culture and indirect immunofluorescence assay (IFA) as conventional diagnostic methods are labor-intensive and time-consuming with limited sensitivity ${ }^{[1]}$. In a study, the isolation of SARS-CoV-2 virus was performed with several cell lines, such as Huh-7 from human 
airway epithelial cells and Vero E6 ${ }^{[9]}$. Clear cytopathic effects (CPE) were observed three days after inoculation. Distinctive crown-like particles were detected with negative staining by transmission electron microscope (TEM) ${ }^{[9]}$. Specimens: The sample collection, quality, transport and, storage play a significant role in screening and detecting SARS-CoV-2 [54]. SARS-CoV-2 as an RNA virus is prone to be destroy and degrade during the processes of sample collection and transportation to the laboratory for testing or due to some technical factors such as operator expertise and PCR inhibition ${ }^{[54]}$. The health worker should wear proper personal protective equipment (PPE) (gloves, gowns, eye protection) to collect specimens. Specimen processing should be performed in accordance with biosafety guideline level 2 or higher [55-56]. Specimens should be delivered to a special laboratory as soon as possible. Up to 72 hours after collection, specimens could be stored at $4^{\circ} \mathrm{C}$, but for longer time, specimens should be store at $-70^{\circ} \mathrm{C}$ or lower temperature ${ }^{[56]}$.

The specimens required for isolation and detection of SARS-CoV-2 include: upper respiratoryspecimens such as oropharyngeal and nasopharyngeal swabs or wash fluid in ambulatory patients, as well as lower respiratory specimens such as endotracheal aspirate, sputum, bronchoalveolar lavage in severe form, and mucus of productive coughs. Additional specimens may be collected from the blood, tissue biopsy, stool, and urine ${ }^{[55-56]}$.

The positive detection rate of SARSCoV-2 in BAL, sputum, nasal swabs, fibro bronchoscope brush biopsy, pharyngeal swabs, feces, blood, and urine were reported $93 \%, 72 \%, 63 \%, 46 \%, 32 \%, 29 \%, 1 \%$ and $0 \%$, respectively. different types of specimen has been reported as follows:, [47]. Evidence shows the shedding of live virus $(14,67)$, indicating the possibility of isolation and detection of virus from stool.
Zhang et al. (2020) found that fecal samples were as suitable as pharyngeal swab for the detection of SARS-CoV-2, yielding similarly accurate results [57]. In another study, the virus detection in the stool swab of patients with negative pharyngeal and nasal swabs was reported to be positive [54]. It was reported that the use of a combination of nasal and stool swabs in SARS-CoV-2 patients screening was more sensitive than either alone ${ }^{[54]}$.

Nucleic acid amplification tests (NAAT) for SARS-CoV-2:

Polymerase chain reaction (PCR) based methods: PCR and qRT-PCR: Nucleic acidbased detection methods have advanced quickly and become an innovative tool for virus detection due to the developments in molecular biology technology, especially PCR-based methods with high specificity, sensitivity, and rapidity of detection. These methods are regarded as the gold standard, routine, and reliable techniques for virus detection ${ }^{[58]}$. In these methods, coronavirus RNA is extracted and converted into cDNA by reverse transcription. The products are analyzed by gel documentation and sequencing, which are the conventional methods for coronaviruses (SARS, MERS viruses) detection ${ }^{[59-60]}$ but are not generally used in clinical samples due to the timeconsuming processes and high cost ${ }^{[58]}$.

The detection based on real-time reverse transcriptase-PCR (RT-PCR) is presently preferred for the detection of coronaviruses owing to its advantages such as specificity, sensitivity, simplicity, and quantitative assay, which provide the possibility of early detection ${ }^{[76-77]}$. As a result, a real time RTPCR based assay is still a primary method for detecting coronaviruses, including SARSCoV-2 [61].

Extensive efforts are being made to improve and advance the real time RT-PCR assay due to the contamination risk, the need for post- 
PCR analysis, and being time-consuming for sample handling. A TaqMan-based real time RT-PCR has been designed with specific primers and probes targeting the $\mathrm{N}$ gene, which could straightforwardly be employed in the routine clinical and diagnostic settings for the detection of HCoVs (229E, OC43) in nasal wash (NW), combined nasal and throat swabs (NTSs), and bronchoalveolar lavage (BAL) specimens ${ }^{[62]}$. Yip et al. (2005) designed a 1-step real-time quantitative RT-PCR (qRT-PCR) assay for SARS-CoV detection using 2 TaqMan probes, instead of 1 probe, with an increase in reaction sensitivity and a detection limit of 1 RNA copy per reaction [63]. The fast-mutation nature of coronaviruses with great mutation rates compared to DNA viruses is considered as an adaptation mechanism for survival and as the intrinsic polymorphic nature of these viruses ${ }^{[48,81]}$, highlighting the necessity for precise detection of these genetically diverse coronaviruses ${ }^{[48,58]}$. For this purpose, multitarget detection real-time RT-PCR methods with appropriate sensitivity have been established for coronavirus. In a study, a real-time RT-PCR test via mismatch-tolerant molecular beacons was developed to detect and distinguish SARS-CoV from pathogenic and non-pathogenic strains. This assay was executed by four beacons, specific for the E, $\mathrm{S}, \mathrm{N}$ and $\mathrm{M}$ genes with an internal positive control (IPC) ${ }^{[64]}$. The assay exhibited high ability for target detection and specificity with a detection limit of 5 copies per reaction $(100 \%)^{[64]}$. This assay provided a simple and fast approach to detect SARS-CoV and a pattern for molecular detection of emerging mutant pathogens ${ }^{[64]}$.

Two RT-PCR assays were recommended by Corman etal. (2014) for human coronaviruses (hCoV-NL63, hCoV-229E, SARS-CoV, hCoVOC43) detection, targeting upstream regions of the E gene (UpE) or within ORF1b for screening and detection, respectively ${ }^{[61]}$. In another study, two real time RT-PCR assays were established, targeting MERS-CoV N gene and upstream regions of MERS-CoV E gene (upE) for the detection and confirmation of MERS-CoV infection in respiratory, serum, and stool specimens ${ }^{[13]}$.

According to several real-time RT-PCR assays applied for coronaviruses, different assays have been announced for the detection of COVID19 causative agent.

A qPCR-based detection method based on the sequence of the RBD of the $S$ gene was proposed by Zhou et al. (2020), but it was not reproducible. Other qPCR targets, including RdRp or E genes, were also recommended for the routine detection of 2019-nCoV [9].

Recently, the World Health Organization (WHO) has declared several primer and probe sets for SARS-CoV-2 detection, which were developed in China, Hong Kong, Japan, Germany, Thailand, Pasteur institute, and USA [36, 61-62, 65-69].

Corman etal.(2020) established and validated a workflow for 2019-nCoV screening and confirmation without virus isolates on Jan 13. They used synthetic nucleic acid technology for designing virus genome closely related to 2003 SARS-CoV [61] before public release of virus sequences from 2019-nCoV cases. They recommended the assay stand on $\mathrm{E}$ gene for the first-line screening tool, followed by RdRp/orf1 gene assay for confirmation. The assay was performed with dual-color technology for discriminating 2019-nCoV (both probes positive) from SARS-CoV RNA (Table 1, Figure 1) ${ }^{[61]}$. The two probes for the second assay included a broad-range reacting probe for SARS-CoV and 2019-nCoV and another probe for annealing only with 2019-nCoV (Table 1) ${ }^{[44]}$. They suggested the pick out of only 2019-nCoV-specific probe, alternatively ${ }^{[61]}$. All assays displayed detection limits of 5.2 and 3.8 copies per reaction for the E and RdRp genes, respectively, displaying high sensitivity; the $\mathrm{N}$ gene had slightly fewer 
sensitivity and was omitted in the second protocol uploaded on Jan 17 by Corman et al. (2020) ${ }^{[61]}$. No cross-reactivity with other coronaviruses or non-specific reactivity between oligonucleotides was detected in all assays ${ }^{[61] .}$

The University of Hong Kong, School of Public Health reported the use of two monoplex assays: the $\mathrm{N}$ gene-targeted RT-PCR assay for screening, which overlaps with SARS-CoV and bat SARS-like coronaviruses, and the Orf1 (ORF1b-NSP14) based assay as a confirmatory assay (Table 1, Figure1). They recommended sequence analysis of products for confirmation and discrimination when the results were positive ${ }^{[65,70]}$. The evaluation of confirmatory assay indicated a wide dynamic range $\left(2^{-4}\right.$ 2000 TCID50/reaction) and exclusivity to COVID19 [65, 70]. However, in-silico analysis indicated the overlapping of confirmatory assays with other coronaviruses genome.

Naganori et al. (2020) in Japan designed a new panel to detect 2019-nCoV: 1) nested RT-PCR and sequencing by 3 primer sets for the Orf1b and $S$ genes, in which the second PCR assay (nested-PCR) was performed after the first PCR, the products were visualized by $2 \%$ agarose gel electrophoresis, and the rest of products were purified and subjected to sequencing with special primers (Table 1 , Figure1) [66], and 2) real-time RT-PCR with specific primers and probes for the $\mathrm{N}$ gene ${ }^{[66]}$ (Table 1, Figure 1). It seems the mentioned $\mathrm{N}$ gene specific primers and probes do not overlap with other coronaviruses according to our in-silico analysis.

Ministry of Public Health, Thailand released a protocol for RT-PCR assays based on the $\mathrm{N}$ gene detection by primers and probes ${ }^{[71]}$, which was indicated to be specific just for COVID 19.

Accordingly, the Centers for Disease Control and Prevention (CDC) of US provided a RTPCR based diagnostic panel for the novel coronavirus ${ }^{[67]}$; accordingly, it was designed with 4 primer pairs, 3 for the $\mathrm{N}$ gene (different region) and one for RNase (Table 1, Figure 1) ${ }^{[67]}$.This panel was recommended for the detection as follows: by $\mathrm{N}^{+}, \mathrm{N}_{2}^{+}, \mathrm{N}^{+}$, and $\mathrm{RP}^{ \pm}$, the result is considered as COVID19 positive, when only one or two of three $\mathrm{N}$ targets are positive and $\mathrm{RP}^{ \pm}$, it is considered as a not conclusive result, and with $\mathrm{N}^{-}, \mathrm{N}^{-}, \mathrm{N}^{-}$, and $\mathrm{RP}^{+}$, the result is considered as COVID19 negative, and negative results for all target genes is considered as invalid ${ }^{[56]}$.

Institute Pasteur of France presented a protocol for SARS-CoV-2 detection, containing 2 series of assays (simplex and multiplex), targeting the $\mathrm{E}$ and RdRp genes (spanning 2 regions), respectively ${ }^{[69]}$. The limit of detection was reported to be about 100 copies of RNA genome per reaction for the $\mathrm{E}$ gene, and 10 copies could be detected with multiplex assay by CI $95 \%{ }^{[69]}$. The specificity of primer and probe sets was evaluated with specimens which were positive for a panel of respiratory viruses; no cross-reactivity was detected ${ }^{[69]}$.

China CDC released a protocolfor the detection of SARS-CoV-2 from clinical specimens based on the $\mathrm{N}$ and ORF1ab genes amplification, in which ORF1ab specific primers and probe were used for confirmation ${ }^{[72]}$ with good sensitivity and specificity. The $\mathrm{N}$ genetargeted primers and probes were applied for screening (Table 1, Figure 1).

In another study, two monoplex real-time RT-PCR assays were performed based on the Hong kong procedure ${ }^{[65]}$, targeting the N gene and RdRP with weak sensitivity.

The high rate of false-negative results is the most commonly reported problem associated with most of the primers and probes used for detection. Jung el al. (2020) performed the first analysis on Feb 25 and compared various primer-probe sets which provided the laboratory confirmation of SARS-CoV-2 ${ }^{[68]}$. They selected 10 primer-probe sets, 7 sets for the $\mathrm{N}$ gene and the other sets for various 
Table 1) Several primers and probes for real-time RT-PCR and nested-PCR detection of SARS-CoV-2

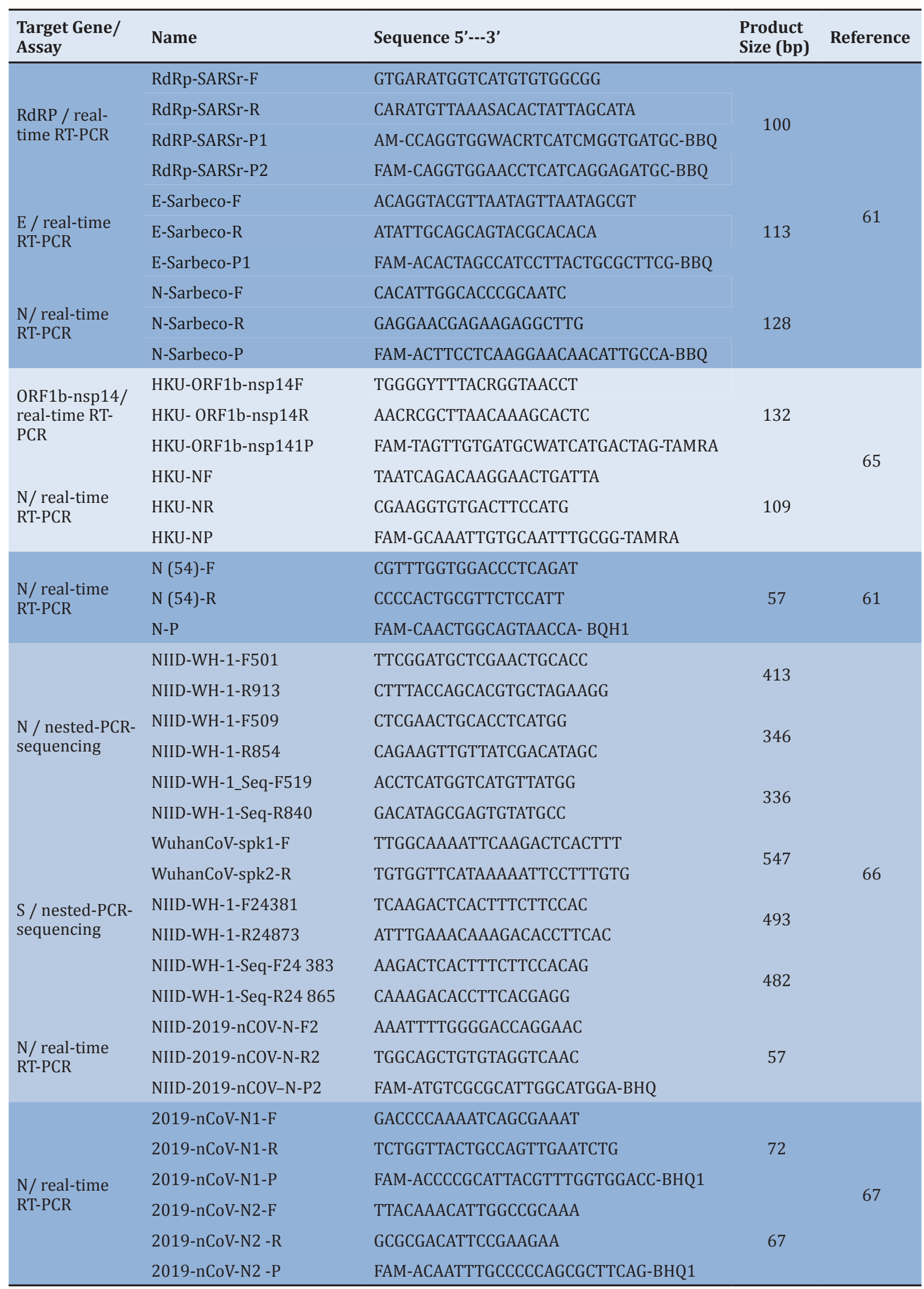


Table 1) continued

\begin{tabular}{|c|c|c|c|c|}
\hline $\begin{array}{l}\text { Target Gene/ } \\
\text { Assay }\end{array}$ & Name & Sequence $5^{\prime}---3^{\prime}$ & $\begin{array}{l}\text { Product } \\
\text { Size (bp) }\end{array}$ & Reference \\
\hline \multirow{3}{*}{$\begin{array}{l}\text { N/ real-time } \\
\text { RT-PCR }\end{array}$} & 2019-nCoV-N3-F & GGGAGCCTTGAATACACCAAAA & \multirow{6}{*}{72} & \multirow{6}{*}{67} \\
\hline & 2019-nCoV-N3-R & TGTAGCACGATTGCAGCATTG & & \\
\hline & 2019-nCoV-N3 -P & FAM-AYCACATTGGCACCCGCAATCCTG-BHQ1 & & \\
\hline \multirow{3}{*}{$\begin{array}{l}\text { RNAse/ real- } \\
\text { time RT-PCR }\end{array}$} & RNAse P-F & AGATTTGGACCTGCGAGCG & & \\
\hline & RNAse P-R & GAGCGGCTGTCTCCACAAGT & & \\
\hline & RNAse P -P & FAM-TTCTGACCTGAAGGCTCTGCGCG- BHQ & & \\
\hline \multirow{3}{*}{$\begin{array}{l}\text { RdRp/Orf1/ } \\
\text { real-time RT- } \\
\text { PCR }\end{array}$} & ORF1ab-F & CCC TGTGGGTTTTACACTTAA & \multirow{2}{*}{119} & \multirow{6}{*}{70} \\
\hline & ORF1ab-R & ACGATTGTGCATCAGCTG A & & \\
\hline & ORF1ab-P & FAM-CCGTCTGCGGTATGTGGAAAGGTTATG G-BHQ1 & \multirow{4}{*}{99} & \\
\hline \multirow{3}{*}{$\begin{array}{l}\text { N/ real-time } \\
\text { RT-PCR }\end{array}$} & $N(60)-F$ & GGGGAACTTCTCCTGCTAGAAT & & \\
\hline & $N(60)-R$ & CAGACATTTTGCTCTCAAGCTG & & \\
\hline & $\mathrm{N}-\mathrm{P}$ & FAM-TTGCTGCTGCTTGACAGATT-BHQ1 & & \\
\hline \multirow{3}{*}{$\begin{array}{l}\text { RdRp/Helicase/ } \\
\text { real-time RT- } \\
\text { PCR }\end{array}$} & RdRp/Helicase-F & CGCATACAGTCTTRCAGGCT & \multirow{3}{*}{134} & \multirow{9}{*}{73} \\
\hline & RdRp/Helicase-R & GTGTGATGTTGAWATGACATGGTC & & \\
\hline & RdRp/Helicase-P & FAM-TTAAGATGTGGTGCTTGCATACGTAGAC-IABkFQ & & \\
\hline \multirow{3}{*}{$\begin{array}{l}\text { S/ real-time } \\
\text { RT-PCR }\end{array}$} & S-F & ССТАСТАAАTTAAATGATCTCTGCTTTACT & \multirow{3}{*}{158} & \\
\hline & S-R & CAAGCTATAACGCAGCCTGTA & & \\
\hline & S-P & HEX-CGCTCCAGGGCAAACTGGAAAG-IABkFQ & & \\
\hline \multirow{3}{*}{$\begin{array}{l}\text { N/ real-time } \\
\text { RT-PCR }\end{array}$} & $N(122)-F$ & GCGTTCTTCGGAATGTCG & \multirow{3}{*}{97} & \\
\hline & $N(122)-R$ & TTGGATCTTTGTCATCCAATTTG & & \\
\hline & $\mathrm{N}-\mathrm{P}$ & FAM-AACGTGGTTGACCTACACAGST-IABkFQ & & \\
\hline \multirow{6}{*}{$\begin{array}{l}\text { RdRp/ real- } \\
\text { time RT-PCR }\end{array}$} & nCoV_IP2-12669-F & ATGAGCTTAGTCCTGTTG & \multirow{2}{*}{108} & \multirow{6}{*}{69} \\
\hline & nCoV_IP2-12759-R & СTCCCTTTGTTGTGTTGT & & \\
\hline & nCoV_IP2-12696bProbe (+) & Hex-AGATGTCTTGTGCTGCCGGTA-BHQ-1 & \multirow{4}{*}{108} & \\
\hline & nCoV_IP4-14059-F & GGTAACTGGTATGATTTCG & & \\
\hline & nCoV_IP4-14146-R & CTGGTCAAGGTTAATATAGG & & \\
\hline & nCoV_IP4-14084Probe(+) & FAM-TCATACAAACCACGCCAGG-BHQ-1 & & \\
\hline
\end{tabular}

regions of the ORF1 gene, including RdRp, ORF1b-Nsp14, and ORF1-Nsp10 according to sequence data from different national institutes ${ }^{[56,61,65-68,71]}$. Among which ORF1ab set was provided by China, targeting the RdRp/Orf1 region; in the case of targeting the N gene, USA recommended N2 and N3; and Japanese provided NIID-2019-nCOV-N sets which displayed the highest sensitivity compared to other sets and was suggested for reliable and sensitive laboratory confirmation of COVID19 ${ }^{[68]}$. According to the results of mentioned studies and our In-silico analysis, it seems the use of a combination of ORF1ab (China CDC); USA-provided 2019-nCoV-N2 and N3; and NIID-2019-nCOV-N by Japan provides appropriate primers and probes to decrease false-negative confirmation of SARS-CoV-2.

Very recently, Yuen et al. (2020) ${ }^{[73]}$ designed a new platform to detect SARS-CoV-2 by 3 novel real time RT-PCR assays targeting the 


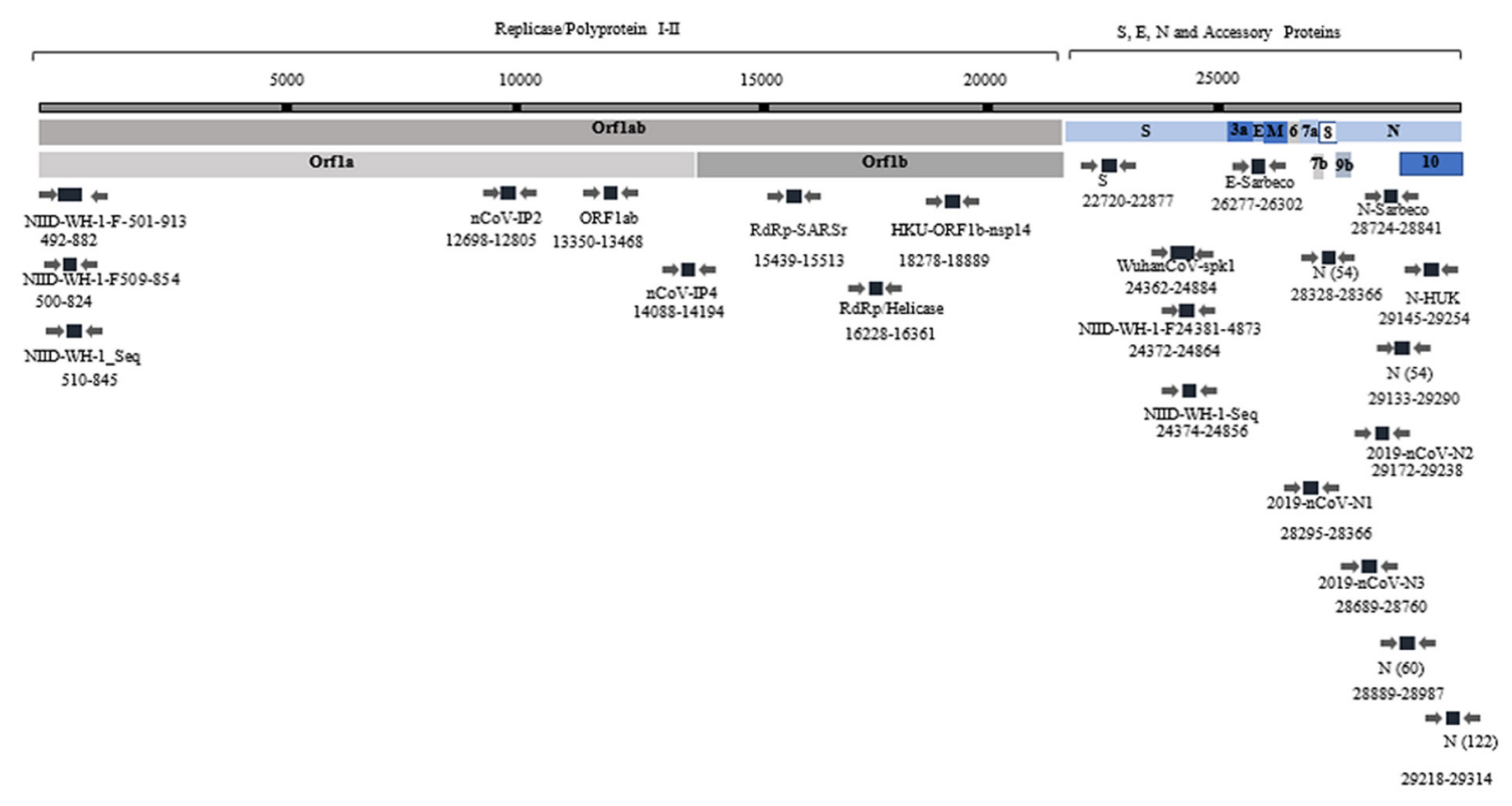

Figure 1: Schematic representation of COVID19 genome and relative position of primers and probes.

RdRp/ Hel, N and S genes of SARS-CoV-2 ${ }^{\text {[73] }}$ and compared the results with PdRp-P2 assay from Berlin protocol [61]. RdRp/Hel assay had the least limit of detection in vitro and was positive in specimens diagnosed as negative by RdRd-P2 [73]. Furthermore, RdRp/Hel assay, unlike RdRp-P2 assay, did not show cross-reactivity with other $\mathrm{HCoV}$ in clinical specimens and cell culture ${ }^{[73]}$. The high sensitivity and specificity of the new RdRp/Hel assay was determined [73], and it was suitable for reducing false negative cases.

Another approach recommended for reducing the false negative detection is the use of a combination of RT-PCR and CT scan ${ }^{[54-55]}$. The accomplishment of both RT-PCR and CT has been determined to have a higher sensitivity (91.9\%) compared to CT (66.7\%) or RT-PCR alone $(78.2 \%)^{[54]}$; indeed, RT-PCR compared to CT is superior in diagnosing mild infections ${ }^{[54]}$. While qRT-PCR method is a gold-standard assay to detect coronaviruses such as MERS and SARS ${ }^{[68,74]}$, the recommended
qRT-PCR assays for SARS-CoV-2 have some alarms: i) cross-reactivity of primers-probes regarding the high similarity of SARS-CoV-2 to SARS-CoV, ii) the assays sensitivity in the detection of the disease in the early stage, RT-PCR assay was reported to be positive in $46.7 \%$ of patients with slight infection [62], iii) false-negative results in patients with positive CT scan results [75-76], IV) the efficiency of molecular diagnostic assay might be correlated to primers, probes, and reagents ${ }^{[68]}$, and false negative results could be caused by poor specimen quality, such as respiratory samples collected from the oropharynx instead of the nasopharynx or sampling in the early or late stage of the disease ${ }^{[54]}, \mathrm{V}$ ) the RT-PCR assays have long turnaround times, are complicated, and usually take an average of more than 2 to 3 hours to generate results; hence, the development of new assays seems to be essential.

Isothermal nucleic acid amplificationbased methods: Numerous molecular assays based on non-PCR methods have been 
established to detect the new coronavirus, such as loop mediated isothermal amplification (LAMP) and nucleic acid sequence-based amplification ${ }^{[58]}$. The LAMP assay requires only a single temperature for amplification, is a quick test, and does not require expensive instruments and reagents. At the end of the reaction, gel electrophoresis is generally used for the analysis of endpoint products. A simple LAMP assay was previously reported for SARS-CoV detection, targeting the orf1b region in the presence of 6 primers ${ }^{[77]}$. The sensitivity of LAMP assay for SARS-CoV detection was similar to those of PCR-based methods [77]. In another study, the LAMP assay was applied for the detection of HCoVNL63 with specific primers designed based on conserved fragment of the $\mathrm{N}$ gene ${ }^{[78]}$. The assay had high specificity and sensitivity with a detection limit of 1 copy of RNA template per reaction ${ }^{[78]}$.

The LAMP assay could also be applied for RNA detection in combination with reverse transcription (RT-LAMP). Shirato et al. (2014) ${ }^{[74]}$ developed a RT-LAMP assay for the detection and epidemiological surveillance of human MERS-CoV with primers targeting conserved region of the $\mathrm{N}$ gene ${ }^{[78]}$. The assay was very specific and did not show crossreactivity with other respiratory viruses ${ }^{[78]}$. The LAMP assay product could be detected by fluorescence dye or the precipitation of magnesium pyrophosphate in real time, resolving the end point detection limit. In a study, a one-step real-time quantitative RT-LAMP assay was developed for the early and rapid diagnosis of SARS-CoV ${ }^{[79]}$. It had a detection limit of 0.01 plaque forming units (PFU) and provided a sensitivity 100-fold higher than that of RT-PCR ${ }^{\text {[79]. }}$

In a study, sequence-specific LAMP-based methods were developed for improving the specificity of assays and separating true signal from nonspecific one ${ }^{[58]}$. In another study, the RT-LAMP assay was improved using a quenching probe (QProbe) for monitoring signal in addition to two primer sets (targeting $\mathrm{N}$ and Orf1a sequences) for the detection of MERS-CoV ${ }^{[80]}$.

Isothermal nucleic acid-based amplification methods could be developed and applied for the detection and confirmation of SARSCoV-2 due to the similarity of the new virus to SARS-CoV and MERS-COV and the success of the LAMP technique in their detection.

Microarray-based methods: Oligonucleotide microarrays have been used for monitoring, detecting, and analyzing virus in clinical samples. In this method, for RNA viruses such as coronavirus, RNA is converted to cDNA, labeled by a specific probe, and fixed on the microarray; thus, the RNA of coronavirus could be detected by a specific probe ${ }^{[58]}$. Shie et al. (2003) designed and synthesized thirty 60 mer specific oligonucleotides according to the sequence of TOR2 (SARS-CoV), which covered the whole genome, ${ }^{[81]}$ and printed them into a microarray. The results indicated that the SARS-CoV genome could be detected separately by the $60 \mathrm{mer}$ oligonucleotide microarray, thereby improving the positive ratio of the diagnosis ${ }^{[81]}$.

Guo et al. (2014) developed a single nucleotide polymorphism (SNP) DNA microarray to detect and genotype the $S$ gene of SARS-CoV with 100\% accuracy ${ }^{[82]}$. Although microarray is a specific and sensitive method, its high cost limits its further application in the detection of coronavirus; therefore, it could be used in SARS-CoV-2 research.

CRISPR diagnostics: Microbial Clustered Regularly Interspaced Short Palindromic Repeats (CRISPR) and CRISPR-associated (CRISPR-Cas) adaptive immune systems have programmable endonucleases that could provide approaches for CRISPR-based diagnostics (CRISPR-Dx) [83]. On March 6, 2020, Broughton et al. released a protocol for 
detecting SARS-CoV-2 based on the extracted sample RNA in approximately 30 minutes by CRISPR- Cas12, called SARS-CoV-2 DETECTR [84]. The nasopharyngeal or oropharyngeal extracted sample RNA was converted to DNA and amplified simultaneously by reverse transcription and loop-mediated amplification (RT-LAMP) with primers targeting the $\mathrm{E}$ and $\mathrm{N}$ genes of SARS-CoV-2; afterwards Cas12-guide RNAs in order to detect three SARS-like coronaviruses (SARSCoV-2, bat SARS-like coronavirus, and SARS$\mathrm{CoV}$ ) in the E gene and specifically to detect SARS-CoV-2 only in the $\mathrm{N}$ gene, detected coronavirus sequences, cleaved reporter molecule, and confirmed virus detection [84]. SARS-CoV-2 DETECTR was evaluated by reference and clinical samples, and the results were determined to be comparable with RT-PCR assay ${ }^{[84]}$.

Zhang et al. (2020) described a protocol for detecting COVID-19 using a CRISPRbased SHERLOCK (Specific High Sensitivity Enzymatic Reporter UnLOCKing) technique [85-86]. At first, extracted/synthetic RNA was amplified by isothermal method with specific primer for the $S$ and Orf1ab genes, followed by the addition of LwaCas13a crRNA for detecting the S and Orf1ab genes ${ }^{85}$. The authors declared that they continue to optimize this protocol ${ }^{[85]}$.

Serological testing: There is no data about the time of antibody production against SARS-CoV-2, since this virus belongs to the viral family causing the MERS and SARS outbreak, the antibody generation time and process is thought to be the same [87]. It has been reported that IgM and IgG antibodies could be detected in the blood of SARS patients 3 and 5 days after the onset of fever, respectively ${ }^{[88]}$. Rapid detection of IgM and IgG antibodies would be valuable in the diagnosis and treatment of SARS-CoV-2 disease.

Serology testing is a substantial assay for the detection of SARS-CoV-2 due to the comparatively short diagnosis time and the possibility of examining an active immune response against pathogen ${ }^{[89]}$. Currently, the standard method to diagnosis disease is PCR based on viral RNA, and no serological test is available ${ }^{[89]}$. Theoretically, the combination of PCR and serological assay seems to increase the detection sensitivity ${ }^{[79]}$. Two possible serological assays would be as follows: i) detection of viral proteins (S, M, $\mathrm{E}$ or $\mathrm{N}$ ) with specific antibodies produced in animal, and ii) ELISA assay which detects patient's antibodies against virus using serum ${ }^{[89]}$.

It has been reported that $\mathrm{N}$ protein of bat SARSr-CoV Rp3 shares 92\% amino acid identity to that of $2019-n \mathrm{CoV}$ and could be used as a target for IgG and IgM enzymesrelated immunosorbent assays (ELISAs) with no cross-reactivity against other human coronaviruses except SARSr-CoV ${ }^{[9]}$.

Tian et al. (2020) reported that human monoclonal antibody CR3022 (specific for S protein RBD domain in SARS-CoV) could bind effectively to 2019-nCoV RBD [90]. It could be related to the identity (73\%) between RBDs in 2019-nCoV and SARS-CoV [90]. It was determined that the CR3022 epitope did not overlap with the binding site of RBD to ACE2 and had the potential to be used as a therapeutic candidate and in vaccine development for SARS-CoV-2 infection [90]. CR3022 has cross-reactivity with SARSCoV and could not be applied to specifically detect the new virus but could be effective in the development of monoclonal antibodies specific for SARS-CoV-2 S protein.

Xiang et al. (2020) evaluated Enzyme-Linked Immunoassay and Colloidal Gold-ImmunoChromatographic Assay Kits (GICA) for SARS-CoV-2 IgM and IgG detection in serum samples ${ }^{[49]}$. The novel coronavirus IgG/IgM antibody ELISA and GICA kits, manufactured by Zhu Hai Liv Zon Diagnostics Inc, China, 
were used to capture and detect viral IgM and IgG according to the manufacturer protocol, and the results were compared by qRTPCR (81). The sensitivity of the combined ELISA and GICA was reported as 87.3 and $82.4 \%$, respectively ${ }^{[49]}$. They concluded the used assays were fast, simple, and safe for COVID-19 diagnosis ${ }^{[49]}$.

Li et al. (2020) developed a rapid and simple immunoassay to simultaneously detect IgM and IgG antibodies against a recombinant RBD of SARS-CoV-2 in the blood within 15 minutes at different infection stages ${ }^{[87]}$. The kit sensitivity and specificity was determined as 88.66 and $90.63 \%$, respectively. This simultaneous antibody detection kit has numerous advantages compared to RTPCR, does not require equipment, is fast and simple, and could be used in any clinic and laboratory, train stations, or airports to screen people, especially asymptomatic people ${ }^{[87]}$. It is more convenient and appropriate to use the blood of finger or heel instead of vein. In a specimen prepared during the early stage of SARS-CoV-2 from throat swab or sputum, the virus may not be detectable, since the combined kit detects IgM and IgG simultaneously, it could be applied for both early stage diagnosis (IgM) as well as for illness monitoring during

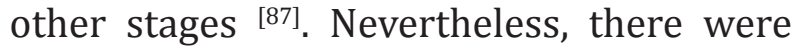
still false negative and false positive cases due to the low antibody concentrations or cross-reactivity with other viruses.

Many antibody detection or virus antigen detection kits are under development.

\section{MALDI TOF-MS and LC-MS technologies}

Matrix-assisted laser desorption/ionization time of flight mass spectrometry (MALDITOF MS) and liquid chromatographymass spectrometry (LC-MS) are analytical chemistry methods which have been highly successful in identifying all classes of biomolecules: proteins, lipids, and nucleic acid. These techniques provide accurate mass information on intact protein/DNA, proteolytic digests or products of mass probe ${ }^{\text {[91-92]. }}$

Xue el al. (2017) established a universal screening method for coronavirus using MALDI-TOF Mass Spectrometry that comprised of a 17-plex analysis to detect six HCoVs in Panel A which included primers and nucleotide extension probes specific to the Orf1 and $\mathrm{N}$ genes of six coronaviruses and primers and probes targeting the Orf1b and upE genes of SARS-CoV and MERS-CoV with ribonuclease $\mathrm{P}$ as internal control, as well as another 17-plex analysis to detect Alphacoronavirus and Betacoronavirus in Panel B which included primers and probes for the RdRp gene in Alphacoronavirus and Betacoronavirus [91, 93]. They reported that the mCoV-MS method is a sensitive and relatively simple assay but may not be successful in detection, especially when the virus load in sample is very low ${ }^{[91]}$. It seems the method could be improved by increasing the number of primers and probes.

Sampath et al. (2005) presented an approach for rapid identification of known and emerging coronaviruses ${ }^{[94]}$. They designed a broad-range PCR targeting regions of Orf1b and NSP14 to amplify nucleic acids of large coronavirus groups; they used electrospray ionization mass spectrometry (EIS) to accurately measure PCR products as well as nucleotide composition analysis to identify viruses. This method was able to detect and distinguish SARS-CoV from others with 1 $\mathrm{PFU} / \mathrm{mL}$ sensitivity ${ }^{[94]}$.

Very recently, Jenkins et al. (2020) developed methods for in-silico detection of SARS-CoV-2 in clinical specimens by LC-MS ${ }^{\left[{ }^{5}\right]}$. At first, they created protein FASTA files and digest map (by shotgun proteomics and trypsin proteolysis); afterward spectral libraries were generated using FASTA files, transition lists were derived from 
libraries (special software), and post translational modifications were identified ${ }^{[96]}$. They provided a procedure for SARS-CoV-2 detection by LC-MS, which continues to be refined.

\section{Conclusion}

In conclusion, the development of new approaches for the treatment and detection of COVID19 could be effective in preventing and decreasing the progression of the disease. In this study, different approaches to treatment were introduced, and different primers and probes for detection were compared. According to our literature review and analysis, the use of a combination of Orf1ab (China CDC), RdRp/ Hel, USA provided 2019-nCoV-N2 and N3, and NIID-2019-nCOV-N by Japan provides appropriate primers and probes to decrease false negative confirmation of SARS-CoV-2. Also, the use of both qRT-PCR and CT-scan is recommend to decrease false negative cases.

Acknowledgments: The authors would like to express their special thanks to staff of Barkat Pharmaceutical group, Tehran, Iran.

Ethical Permission: The study was approved by the Ethics Committee of Islamic Azad University of Tehran Medical science (No: IR.IAU.PS.REC.1399.102).

Conflict of Interests: The authors declare that there is no conflict of interest.

Authors' Contribution: Conceptualization: HMB, BD; Data collection and analysis: HMB, $\mathrm{BD}$; Interpretation of the results: $\mathrm{HMB}, \mathrm{BD}$; Writing of original draft: HMB; Writing, reviewing and editing: BD. All authors read and approved the manuscript.

Fundings: No funding is reported.

Consent to participate: Not applicable.

\section{References}

1. Zhang N, Wang L, Deng X, Liang R, Su M, He $C$, et al. Recent advances in the detection of respiratory virus infection in humans. J
Med Virol. 2020;92(4):408-17.

2. Huang $\mathrm{P}$, Wang $\mathrm{H}, \mathrm{Cao} Z$, Jin $\mathrm{H}$, Chi $\mathrm{H}$, Zhao J, et al. A rapid and specific assay for the detection of MERS-CoV. Front Microbiol. 2018;9:1101.

3. Gorbalenya AE, Enjuanes L, Ziebuhr J, Snijder EJ. Nidovirales: Evolving the largest RNA virus genome. Virus Res. 2006;117(1):17-37.

4. Channappanavar R, Perlman S. Pathogenic human coronavirus infections: Causes and consequences of cytokine storm and immunopathology. Semin Immunopathol. 2017;39(5):52939.

5. Xie C, Jiang L, Huang G, Pu H, Gong B, Lin $\mathrm{H}$, et al. Comparison of different samples for 2019 novel coronavirus detection by nucleic acid amplification tests. Int J Infect Dis. 2020.

6. Wu F, Zhao S, Yu B, Chen Y-M, Wang W, Song $\mathrm{Z}-\mathrm{G}$, et al. A new coronavirus associated with human respiratory disease in China. Nature. 2020;579(7798):265-9.

7. World Health Organization. Coronavirus disease 2019 (COVID-19) Situation Report -59 .

8. World Health Organization. Timeline: WHO's COVID-19 response?

9. Zhou P, Yang X-L, Wang X-G, Hu B, Zhang L, Zhang W, et al. A pneumonia outbreak associated with a new coronavirus of probable bat origin. Nature. 2020;579(7798):270-3.

10. Cascella M, Rajnik M, Cuomo A, Dulebohn SC, Di Napoli R. Features, evaluation, and treatment coronavirus (COVID-19). StatPearls Publishing; 2020.

11. Chan JF-W, Kok K-H, Zhu Z, Chu H, To KKW, Yuan S, et al. Genomic characterization of the 2019 novel human-pathogenic coronavirus isolated from a patient with atypical pneumonia after visiting Wuhan. Emerg Microbes Infect. 2020;9(1):221-36. 12. Perlman S, Netland J. Coronaviruses 
post-SARS: Update on replication and pathogenesis. Nat Rev Microbiol. 2009;7(6):439-50.

13. Lu X, Whitaker B, Sakthivel SKK, Kamili S, Rose LE, Lowe L, et al. Real-time reverse transcription-pcr assay panel for middle east respiratory syndrome coronavirus. J Clin Microbiol. 2014;52(1):67-75.

14. Li F. Structure, function, and evolution of coronavirus spike proteins. Annu Rev Virol. 2016;3(1):237-61.

15. Rothan HA, Byrareddy SN. The epidemiology and pathogenesis of coronavirus disease (COVID-19) outbreak. J Autoimmun. 2020;109:102433.

16. Lei J, Li J, Li X, Qi X. CT imaging of the 2019 novel coronavirus (2019-nCoV) Pneumonia. Radiology. 2020;295(1):18.

17. Huang C, Wang Y, Li X, Ren L, Zhao J, Hu Y, et al. Clinical features of patients infected with 2019 novel coronavirus in Wuhan, China. Lancet. 2020;395(10223):497506.

18. Wrapp D, Wang N, Corbett KS, Goldsmith JA, Hsieh C-L, Abiona O, et al. Cryo-EM structure of the 2019-nCoV spike in the prefusion conformation. BioRxiv. 2020.

19. Wan Y, Shang J, Graham R, Baric RS, Li F. Receptor recognition by the novel coronavirus from Wuhan: An analysis based on decade-long structural studies of SARS coronavirus. J Virol. 2020;94(7):e00127

20. Imai Y, Kuba K, Rao S, Huan Y, Guo F, Guan $\mathrm{B}$, et al. Angiotensin-converting enzyme 2 protects from severe acute lung failure. Nature. 2005;436(7047):112-6.

21. Zhao Y, Zhao Z, Wang Y, Zhou Y, Ma Y, Zuo W. Single-cell RNA expression profiling of ACE2, the putative receptor of Wuhan 2019-nCov. BioRxiv. 2020.

22. Zhang H, Kang Z, Gong H, Xu D, Wang $\mathrm{J}, \mathrm{Li} \mathrm{Z}$, et al. The digestive system is a potential route of 2019-nCov infection: A bioinformatics analysis based on single- cell transcriptomes. BioRxiv. 2020.

23. Chai X, Hu L, Zhang Y, Han W, Lu Z, Ke $A$, et al. Specific ACE2 expression in cholangiocytes may cause liver damage after 2019-nCoV infection. BioRxiv. 2020.

24. Zou X, Chen K, Zou J, Han P, Hao J, Han $Z$, et al. Single-cell RNA-seq data analysis on the receptor ACE2 expression reveals the potential risk of different human organs vulnerable to Wuhan 2019-nCoV infection. Front Med. 2020;14(2):18592.

25. Xu H, Zhong L, Deng J, Peng J, Dan H, Zeng $X$, et al. High expression of ACE2 receptor of $2019-n \mathrm{CoV}$ on the epithelial cells of oral mucosa. Int J Oral Sci. 2020;12(1):8.

26. Zhang H, Penninger JM, Li Y, Zhong N, Slutsky AS. Angiotensin-converting enzyme 2 (ACE2) as a SARS-CoV-2 receptor: Molecular mechanisms and potential therapeutic target. Intensive Care Med. 2020;46(4):586-90.

27. Hoffmann M, Kleine-Weber $H$, Krüger N, Müller M, Drosten C, Pöhlmann S. The novel coronavirus 2019 (2019-nCoV) uses the SARS-coronavirus receptor ACE2 and the cellular protease TMPRSS2 for entry into target cells. BioRxiv. 2020.

28. Shehata MM, Gomaa MR, Ali MA, Kayali G. Middle East respiratory syndrome coronavirus: a comprehensive review. Front Med. 2016; 10(2): 120-136

29. Iwata-Yoshikawa N, Okamura T, Shimizu Y, Hasegawa H, Takeda M, Nagata N. TMPRSS2 contributes to virus spread and immunopathology in the airways of murine models after coronavirus infection. J Virol. 2019;93(6):e01815-18.

30. Belouzard S, Chu VC, Whittaker GR. Activation of the SARS coronavirus spike protein via sequential proteolytic cleavage at two distinct sites. Proc Natl Acad Sci. 2009;106(14):5871-6.

31. Mille JK, Whittaker GR. Host cell entry of Middle East respiratory syndrome 
coronavirus after two-step, furin-mediated activation of the spike protein. Proc Natl Acad Sci. 2014;111(42):15214-9.

32. Wang H, Yang P, Liu K, Guo F, Zhang Y, Zhang $G$, et al. SARS coronavirus entry into host cells through a novel clathrinand caveolae-independent endocytic pathway. Cell Res. 2008;18(2):290-301.

33. De Wit E, Van Doremalen N, Falzarano D, Munster VJ. SARS and MERS: Recent insights into emerging coronaviruses. Nat Rev Microbiol. 2016;14(8):523-34.

34. Li X, Geng M, Peng Y, Meng L, Lu S. Molecular immune pathogenesis and diagnosis of COVID-19. J Pharm Anal. 2020;10(2):102-8.

35. Zhu J, Yamane H, Paul WE. Differentiation of effector CD4 T cell populations. Annu Rev Immunol. 2010;28:445-89.

36. Diao B, Wang C, Tan Y, Chen X, Liu Y, Ning $L$, et al. Reduction and functional exhaustion of $\mathrm{T}$ cells in patients with coronavirus disease 2019 (COVID-19). MedRxiv. 2020.

37. Qin C, Zhou L, Hu Z, Zhang S, Yang S, Tao Y, et al. Dysregulation of immune response in patients with COVID-19 in Wuhan, China. Clin Infect Dis. 2020;71(15):7628.

38. Min CK, Cheon S, Ha NY, Sohn KM, Kim Y, Aigerim A, et al. Comparative and kinetic analysis of viral shedding and immunological responses in MERS patients representing a broad spectrum of disease severity. Sci Rep. 2016;6(1):1-2.

39. Li G, Chen X, Xu A. Profile of specific antibodies to the SARSassociated coronavirus. N Engl J Med. 2003;349(5):508-9.

40. Snijder EJ, Van der Meer Y, ZevenhovenDobbe J, Onderwater JJM, Van der Meulen J, Koerten HK, et al. Ultrastructure and origin of membrane vesicles associated with the severe acute respiratory syndrome coronavirus replication complex. J Virol. 2006;80(12):5927-40.

41. Belser JA, Rota PA, Tumpey TM. Ocular tropism of respiratory viruses. Microbiol Mol Biol Rev. 2013;77(1):144-56.

42. Lu CW, Liu XF, Jia ZF. 2019-nCoV transmission through the ocular surface must not be ignored. Lancet. 2020;395(10224):e39.

43. Peng X, Xu X, Li Y, Cheng L, Zhou X, Ren B. Transmission routes of $2019-\mathrm{nCoV}$ and controls in dental practice. Int J Oral Sci. 2020;12(1):1-6.

44. To KK, Tsang OT, Yip CC, Chan KH, Wu TC, Chan JM. Consistent detection of 2019 novel coronavirus in Saliva. Clin Infect Dis. 2020;71(15):841-3.

45. Cooley H, Gleick PH, Abraham S, Cai W. Water and the COVID-19 Pandemic: Impacts on Municipal Water Demand. 2020 July.

46. Xiao F, Tang M, Zheng X, Li C, He J, Hong $\mathrm{Z}$, et al. Evidence for gastrointestinal infection of SARS-CoV-2. MedRxiv. 2020.

47. Wang W, Xu Y, Gao R, Lu R, Han K, Wu G, et al. Detection of SARS-CoV-2 in different types of clinical specimens. JAMA. 2020;323(18):1843-4.

48. SeahI,SuX,Lingam G. Revisiting the dangers of the coronavirus in the ophthalmology practice. Eye. 2020;34(7):1155-7.

49. Xiang J, Yan M, Li H, Liu T, Lin C, Huang $S$, et al. Evaluation of enzyme-linked immunoassay and colloidal goldimmunochromatographic assay kit for detection of novel coronavirus (SARSCov-2) causing an outbreak of pneumonia (COVID-19). MedRxiv. 2020.

50. Shanmugaraj B, Siriwattananon K, Wangkanont K, Phoolcharoen W. Allergy and immunology perspectives on monoclonal antibody therapy as potential therapeutic intervention for Coronavirus disease-19 (COVID-19). Asian Pac J Allergy Immunol. 2020;38(1):10-8.

51. Guan W-J, Ni Z-Y, Hu Y, Liang W-H, Ou 
C-Q, He J-X, et al. Clinical characteristics of coronavirus disease 2019 in China. N Engl J Med. 2020;382(18):1708-20.

52. Pan Y, Guan H, Zhou S, Wang Y, Li Q Zhu $\mathrm{T}$, et al. Initial CT findings and temporal changes in patients with the novel coronavirus pneumonia (2019-nCoV): A study of 63 patients in Wuhan, China. Eur Radiol. 2020;30(6):3306-9.

53. Shi H, Han X, Jiang N, Cao Y, Alwalid O, $\mathrm{Gu} \mathrm{J}$, et al. Radiological findings from 81 patients with COVID-19 pneumonia in Wuhan, China: A descriptive study. Lancet Infect Dis. 2020;20(4):425-34.

54. Jiang G, Renc X, Liu Y, Chen H, Liu W, Guo $\mathrm{Z}$, et al. Application and optimization of RT-PCR in diagnosis of SARS-CoV-2 infection. MedRxiv. 2020.

55. World Health Organization. Coronavirus disease (COVID-19) technical guidance: Laboratory testing for 2019-nCoV in humans. 2020.

56. Centers for Disease Control and Prevention. Real-time RT-PCR panel for detection 2019-nCoV. CDC; 2020.

57. Zhang J, Wang S, Xue Y. Fecal specimen diagnosis 2019 novel Coronavirusinfected pneumonia. J Med Virol. 2020;92(6):680-2.

58. Shen M, Zhou Y, Ye J, Abdullah ALmaskri AA, Kang Y, et al. Recent advances and perspectives of nucleic acid detection for coronavirus. J Pharm Anal. 2020;10(2):97-101.

59. Setianingsih TY, Wiyatno A, Hartono TS, Hindawati E, Rosamarlina, Dewantari $\mathrm{AK}$, et al. Detection of multiple viral sequences in the respiratory tract samples of suspected Middle East respiratory syndrome coronavirus patients in Jakarta, Indonesia 20152016. Int J Infect Dis. 2019;86:102-7.

60. Adachi D, Johnson G, Draker R, Ayers M, Mazzulli T, Talbot PJ, et al. Comprehensive detection and identification of human coronaviruses, including the SARS-associated coronavirus, with a single RT-PCR assay. J Virol Methods. 2004;122(1):29-36.

61. Corman VM, Landt 0 , Kaiser $M$, Molenkamp R, Meijer A, Chu DK, et al. Detection of 2019 novel coronavirus (2019-nCoV) by real-time RT-PCR. Euro Surveill. 2020;25(3):2000045.

62. Van Elden LJR, Van Loon AM, Van Alphen F, Hendriksen KAW, Hoepelman AIM, van Kraaij MGJ, et al. Frequent detection of human coronaviruses in clinical specimens from patients with respiratory tract infection by use of a novel real-time reverse-transcriptase polymerase chain reaction. J Infect Dis. 2004;189(4):652-7.

63. Yip SP, To SST, Leung PH, Cheung TS, Cheng PK, Lim WW. Use of dual TaqMan probes to increase the sensitivity of 1-step quantitative reverse transcription-PCR: Application to the detection of SARS Coronavirus. Clin Chem. 2005;51(10):1885-8.

64. Hadjinicolaou AV, Farcas GA, Demetriou VL, Mazzulli T, Poutanen SM, Willey BM, et al. Development of a molecularbeacon-based multi-allelic real-time RTPCR assay for the detection of human coronavirus causing severe acute respiratory syndrome (SARS-CoV): A general methodology for detecting rapidly mutating viruses. Arch Virol. 2011;156(4):671-80.

65. HKU Med. Detection of 2019 novel coronavirus (2019-nCoV) in suspected human cases by RT-PCR. 2020.

66. Nao N, Shirato K, Katano H, Matsuyama $\mathrm{S}$, Takeda M. Detection of second case of 2019-nCoV infection in Japan. Natl Inst Infect Dis. 2020.

67. Centers for Disease Control and Prevention. 2019-novel coronavirus (2019-nCoV) real-time rRT-PCR panel primers and probes. USA: Department of 
Health and Human Services; 2020, p. 2.

68. Jung YJ, Park G-S, Moon JH, Ku K, Beak $\mathrm{S}-\mathrm{H}$, Kim S, et al. Comparative analysis of primer-probe sets for the laboratory confirmation of SARS-CoV-2. BioRxiv 2020.

69. World Health Organization. Protocol: Real-time RT-PCR assays for the detection of SARS-CoV-2. Geneva: World Health Organization; 2020.

70. Chu DKW, Pan Y, Cheng SMS, Hui KPY, Krishnan P, Liu Y, et al. Molecular diagnosis of a novel coronavirus (2019$\mathrm{nCoV}$ ) causing an outbreak of pneumonia. Clin Chem. 2020;66(4):549-55

71. Corman VM, Landt 0 , Kaiser $M$, Molenkamp R, Meijer A, Chu DKW, et al. Diagnostic detection of Novel coronavirus 2019 by Real time RTPCR. Euro Surveill. 2020;25(3):2000045.

72. WOrld Health Organization. Country \& Technical Guidance - Coronavirus disease (COVID-19).

73. Chan JF-W, Yip CC-Y, To KK-W, Tang THC, Wong SC-Y, Leung K-H, et al. Improved molecular diagnosis of COVID-19 by the novel, highly sensitive and specific COVID-19-RdRp/Hel real-time reverse transcription-polymerase chain reaction assay validated in vitro and with clinical specimens. J Clin Microbiol. 2020;58(5):e00310-20.

74. Corman VM, Eckerle I, Bleicker T, Zaki A, Landt 0, Eschbach-Bludau $M$, et al. Detection of a novel human coronavirus by real-time reversetranscription polymerase chain reaction. Eurosurveillance. 2012;17(39):20285

75. Lan L, Xu D, Ye G, Xia C, Wang S, Li Y, et al. Positive RT-PCR test results in patients recovered from COVID-19. JAMA. 2020;323(15):1502-3.

76. Xie X, Zhong Z, Zhao W, Zheng C, Wang F, Liu J. et al. Chest CT for typical 2019nCoV pneumonia: Relationship to negative RT-PCR testing. Radiology. 2020;296(2):E41-5.

77. Poon LLM, Leung CSW, Tashiro M, Chan $\mathrm{KH}$, Wong BWY, Yuen KY, et al. Rapid detection of the severe acute respiratory syndrome (SARS) coronavirus by a loopmediated isothermal amplification assay. Clin Chem. 2004;50(6):1050-2.

78. Pyrc K, Milewska A, Potempa J. Development of loop-mediated isothermal amplification assay for detection of human coronavirus-NL63. J Virol Methods. 2011;175(1):133-6.

79. Thai HTC, Le MQ Vuong CD, Parida $\mathrm{M}$, Minekawa $\mathrm{H}$, Notomi $\mathrm{T}$, et al. Development and evaluation of a novel loop-mediated isothermal amplification method for rapid detection of severe acute respiratory syndrome coronavirus. J Clin Microbiol. 2004; 42(5):1956-61.

80. Shirato K, Semba S, El-Kafrawy SA, Hassan AM, Tolah AM, Takayama I, et al. Development of fluorescent reverse transcription loop-mediated isothermal amplification(RT-LAMP) usingquenching probes for the detection of the Middle East respiratory syndrome coronavirus. J Virol Methods. 2018;258:41-8.

81. Shi R, Ma W, Wu Q, Zhang B, Song Y, Guo $\mathrm{Q}$, et al. Design and application of $60 \mathrm{mer}$ oligonucleotide microarray in SARS coronavirus detection. Chinese Sci Bull. 2003;48(12):1165-9.

82. Guo X, Geng P, Wang Q, Cao B, Liu B. Development of a single nucleotide polymorphism DNA microarray for the detection and genotyping of the SARS coronavirus. J Microbiol Biotechnol. 2014;24(10):1145-454.

83. Gootenberg JS, Abudayyeh 00, Lee JW, EssletzbichlerP,Dy AJ,JoungJ,etal.Nucleic acid detection with CRISPR-Cas13a/ C2c2. Science. 2017;356(6336):438-42.

84. Broughton JP, Deng X, Yu G, Fasching CL, Singh J, Streithorst J, et al. Rapid detection 
of 2019 novel coronavirus SARS-CoV-2 using a CRISPR-based DETECTR Lateral Flow Assay. MedRxiv. 2020.

85. Zhang F, Abudayyeh 00, Gootenberg JS. A protocol for detection of COVID-19 using CRISPR diagnostics. 2020:8.

86. Hou T, Zeng W, Yang M, Chen W, Ren L, Ai J, et al. Development and evaluation of A CRISPR-based diagnostic for 2019-novel coronavirus. MedRxiv. 2020.

87. Li Z, Yi Y, Luo X, Xiong N, Liu Y, Li S, et al. Development and clinical application of a aapid IgM-IgG combined antibody test for SARS-CoV-2 infection diagnosis. J Med Virol. 2020.

88. Chen X, Zhou B, Li M, Liang X, Wang H, Yang $G$, et al. Serology of severe acute respiratory syndrome: Implications for surveillance and outcome. J Infect Dis. 2004;189(7):1158-63.

89. Serology testing and COVID-19 - What We Know So Far. Public Health Ontario. 2020.

90. Tian X, Li C, Huang A, Xia S, Lu S, Shi Z, etal. Potent binding of 2019 novel coronavirus spike protein by a SARS coronavirusspecific human monoclonal antibody.
Emerg Microbes Infect. 2020;9(1):382-5. 91. Liu N, Wang L, Cai G, Zhang D, Lin J. Establishment of a simultaneous detection method for ten duck viruses using MALDI-TOF mass spectrometry. J Virol Methods. 2019;273:113723.

92. Trauger SA, Junker T, Siuzdak G. Investigating viral proteins and intact viruses with mass spectrometry. Berlin, Heidelberg: Springer; 2003, pp. 265-82.

93. Xiu L, Zhang C, Wu Z, Peng J. Establishment and application of a universal coronavirus screening method using MALDI-TOF mass spectrometry. Front Microbiol. 2017;8:1510.

94. Sampath R, Hofstadler SA, Blyn LB, Eshoo MW, Hall TA, Massire C, et al. Rapid identification of emerging pathogens: Coronavirus. Emerg Infect Dis. 2005;11(3):373-9.

95. Jenkins C, Orsburn B. In silico approach to accelerate the development of mass spectrometry-based proteomics methods for detection of viral proteins: Application to COVID-19. BioRxiv. 2020.

96. Jenkins $C$, Orsburn B. In silico approach to accelerate the development of 